\title{
Hva er en psykiater?
}

\author{
Psykiaterens rolle og identitet er et viktig tema for psykiaterne selv, \\ men i høy grad også for pasienter, medarbeidere og samfunnet gene- \\ relt. Hva slags psykiater vil vi ha i vår tids helsevesen? Hvilke helter \\ har psykiaterne for sin virksomhet? Hvordan opplever unge kolleger \\ psykiateren? Hva er psykiaterens kjerneidentitet når det gjelder \\ kunnskaper, ferdigheter og holdninger, og kan den bestå i dag?
}

Kronikken er basert på et plenumsforedrag ved Norsk Psykiatrisk Forenings 100- årsjubileum

\section{Per Vaglum}

per.vaglum@medisin.uio.no

Avdeling for medisinske atferdsfag

Institutt for medisinske basalfag

Det medisinske fakultet

Universitetet i Oslo

Boks 1111 Blindern

0319 Oslo 3

Synet på hva det er å være psykiater varierer sterkt alt etter ståsted. Går vi til mediene, finner vi relativt ofte generelle, kritiske beskrivelser av psykiaterne som folk som sykeliggjør normale reaksjoner og setter folk i båser med sin diagnostikk. Ofte heter det at de reduserer alt det menneskelige til biologi og dermed ødelegger pasienten med sin ensidige biologiske behandling. De mangler dessuten interesse for pasienten som person, de liker å påtvinge folk hjelp de ikke ønsker og er dessuten politisk naive. Psykiaterne selv oppfatter seg imidlertid som de svakes hjelpere og forsvarere, som kjemper for å sidestille psykiske og somatiske pasienter når det gjelder økonomi og behandlingsressurser. Del av deres selvforståelse er også at de nedkjemper all psykisk lidelse med effektive og skånsomst mulige midler, at de hindrer folk i å ødelegge for seg selv og at de er gode i samtalens, empatiens og selvrefleksjonens kunst.

\section{Finnes det en felles psykiateridentitet?}

Vi er alle unike som mennesker. Og hver psykiater er til en viss grad psykiater på sin måte - og til en viss grad forskjellig i forhold til ulike pasienter. Også synet på etiologi, patogenese og valg av behandlingsmetoder varierer innen fagfeltet. Denne variasjonen kan for utenforstående iblant fortone seg som så stor at det blir umulig å tenke seg en felles psykiateridentitet. Uten en slik kjerne av felles identitet er imidlertid risikoen stor for at psykiatri som en egen profesjon fragmenteres. Det er derfor viktig å prøve å identifisere trekk som de fleste i faget vil kunne kjenne seg igjen i. Det er det jeg har forsøkt å gjøre i denne kronikken.

Erikson definerte en persons identitet som opplevelsen av seg selv som en unik, sammenhengende psykisk enhet som er permanent til stede og vil være den samme over tid - uavhengig av ytre miljø eller indre psykiske forhold (1). Utviklingen av en faglig identitet har mye å gjøre med hvem vi identifiserer oss med, hvem vi vil være lik, hvem som er heltene. En gruppes identitet er basert på dens forskjellighet fra alle andre grupper. Psykiaterne må ha en identitet som skiller dem noe ut fra andre leger, ikke bare fra pasienter og befolkningen i sin alminnelighet. For å komme på sporet av en mulig psykiateridentitet har jeg stilt meg tre spørsmål: Hvem er psykiaternes helter? Hvordan oppfatter unge kolleger hva som kjennetegner psykiateridentiteten? Er det noen kunnskaper, ferdigheter og holdninger som skiller psykiateren fra andre leger?

\section{Heltene og heltinnene}

Sigmund Freud (1856-1939) og Melanie Klein (1882-1960) står for respekten for det irrasjonelle mennesket, for erkjennelsen av at vi aldri har full oversikt over våre motiver fordi noen er ubevisste eller automatiske. Anna Freud (1885-1982) tilføyde betydningen av adekvate og tilpasningsfremmende mestringsmåter for god psykisk helse. Og Karen Horney (1885-1952) trakk frem hvordan denne helsen ikke bare påvirkes av den egne personligheten, men også den kulturelle kontekst vi befinner oss i. John Bowlby (1907-90) og Virginia Satir (1916-88) klargjorde hvordan barnets tidlige tilknytningsmønstre og barns, ungdoms og voksnes aktuelle nære relasjoner påvir- ker selvtillit og den psykiske helsen. Nordmannen Herluf Thomstad (1905-2000) og Ronald D. Laing (1927-89) ga makt og verdighet til de psykiatriske pasienter. Og Siegfried Foulkes (1898-1976), Heinz Kohut (1913-1981), Otto F. Kernberg (f. 1928) og Aaron Beck (f. 1921) med flere har påvist den engasjerte og empatiske samtalens og psykoterapiens kraft. Nå er to av tidens helter Kenneth Kendler og Peter Fonagy (f. 1952), som begge integrerer en genetisk/biologisk med en psykologisk/ sosial forståelse av psykiske lidelser.

\section{Nybegynnerens oppfatning av rollen} Til et av de obligatoriske grunnseminarene i psykiatri har jeg over år bedt deltakerne om å ta med et dikt som de mener godt illustrerer psykiaterens rolle og identitet. Helt kort oppsummert har de vanligste temaene i disse diktene vært: ydmykhet som hjelper, formidling av håp, toleranse for forskjellighet hos en selv og andre, egen frykt for følelser, verdien av en god nær relasjon og at vi må gå veien sammen med pasientene. Oddmund Haugens dikt er et eksempel som illustrerer det siste temaet (2):

\section{Over desse bruene}

Her vert bruene smalare men saman eig vi styrke til à vandre vidare du og eg.

\section{Her vert gjerda altfor høge-} men om vi leitar $i$ lag finn vi ein inngang du og eg.

\section{Her stengjer murane} og gjer oss usynlegeMen frå innsida stig ropet om ein utgang for deg og meg.

Her - hos kvarandre

finst desse bruene som vi treng.

Det kan være vanskelig å finne dikt om ingeniører eller maskinreparatører. Til meg forteller diktene at de som begynner på psykiatriutdanning, er svært oppmerksom på at de, uansett type jobb, skal inn i en vanskelig, mellommenneskelig relasjon. Og at det er følelser og ikke bare kjemiske prosesser de kommer til å måtte forholde seg til. 


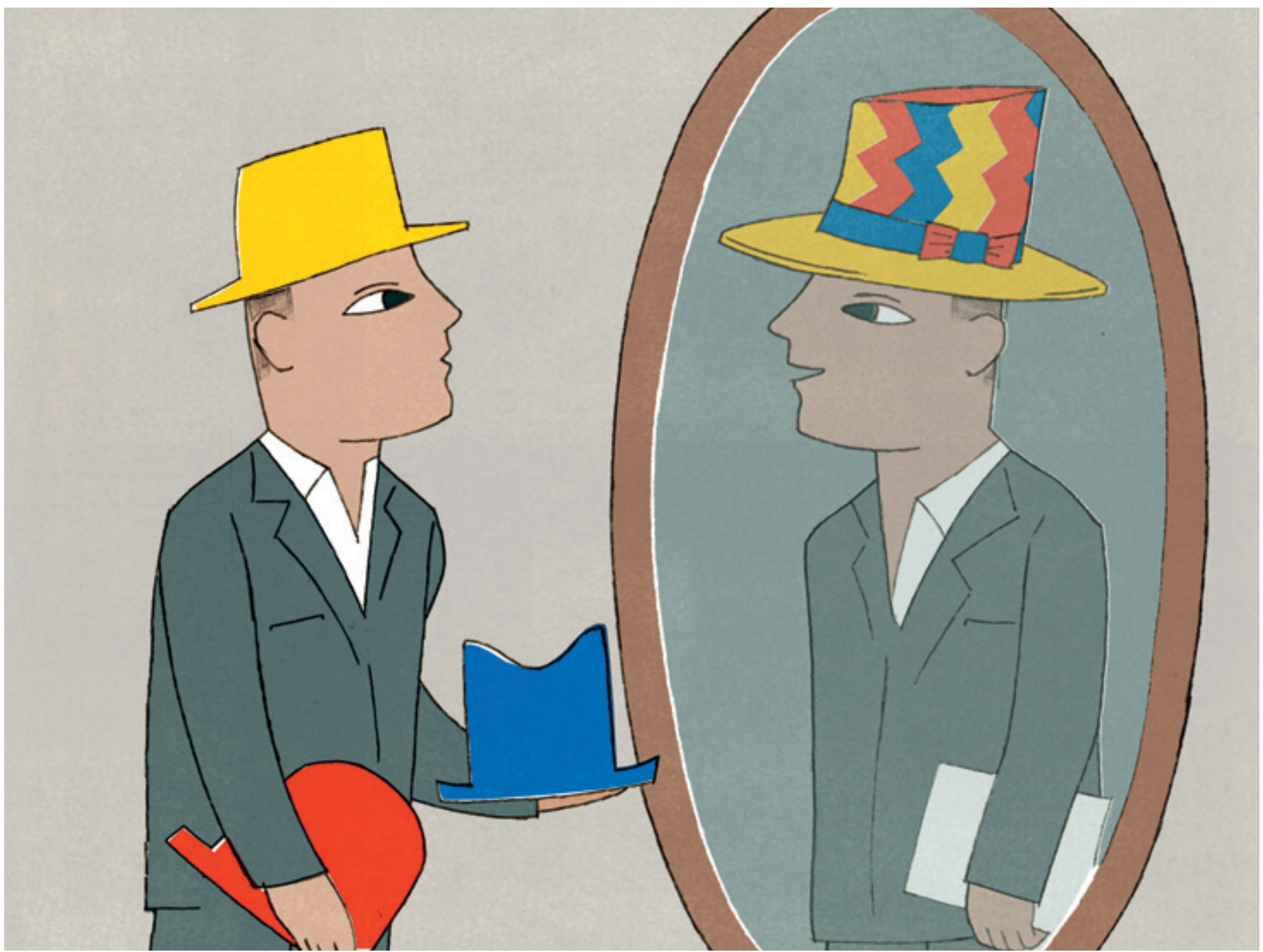

Illustrasjon Kari Stai, Patron

\section{Hva skiller psykiateren fra andre leger?}

Den profesjonelle identitet bygger på integreringen av kunnskaper, ferdigheter og holdninger (3). I det følgende har jeg forsøkt å identifisere visse kjennetegn som jeg hevder at utgjør kjernen i den psykiateridentiteten som utformet seg $i$ årene fra 1960 og til nå.

\section{Kjernekunnskapene}

Psykiatrisk teori er i prinsippet reduksjonistisk og er utviklet med det formål å være et brukbart grunnlag for å diagnostisere og behandle psykiske lidelser og til å forebygge psykisk sykelighet. Den er ikke ment å kunne totalforklare eller å forstå hele livet eller mennesket. Alle psykiske lidelser forstås av den moderne psykiater ut fra «stresssårbarhets-modellen» (4). En psykisk lidelse oppstår og forløper i et samspill mellom biologiske, psykologiske, sosiale og kulturelle faktorer. Den relative betydning av hver enkelt faktor kan variere fra pasient til pasient og fra fase til fase i sykdomsforløpet. Behandlingsfokus kan derfor også variere innenfor grove diagnosegrupper.
Kunnskap om eksterne stressfaktorer i pasientens liv er spesielt viktig for å identifisere faktorer som utløser, vedlikeholder eller forverrer forløp av psykiske lidelser og for å forebygge tilbakefall. Mellommenneskelige relasjoner (f.eks. familien, kolleger) kan både være stressfaktorer og beskyttelsesfaktorer i forhold til psykisk helse. Personlighetstype, personlighetsforstyrrelser og dårlig mestring er viktige sårbarhetsfaktorer som kan modifiseres eller endres gjennom psykoterapi. Og endelig: Legepasient-relasjonens kvalitet påvirker forløpet av psykiske lidelser og er viktig for etterlevelse av behandling.

\section{Kjerneferdighetene}

Psykiateren skal mestre samarbeidet også med såkalt «vanskelige» mennesker, med de redde, forvirrede eller aggressive pasientene og med dem som er «sendt av andre». Psykiateren skal også klare å få til et samarbeid med mennesker som psykiateren selv kanskje aldri ville hatt som venn eller hilst på som nabo. Ved valg av tiltak er det viktig å alltid vurdere den relative (varierende) betydning de biologiske, psykologiske og miljømessige faktorer har hos den enkelte pasient. Psykiateren kan bruke lege-pasientrelasjonen terapeutisk og vet hvilke irrasjonelle faktorer som kan opptre i dette forholdet (f.eks. overføring, motoverføring, motstand) (5). Psykiateren kan også gjennomføre konstruktive familiesamtaler der dette er indisert, bør kjenne indikasjoner og kontraindikasjoner for de spesifikke biologiske/psykoterapeutiske/sosiale behandlingsmetoder og kan selv utøve flere av disse. Psykiateren er godt i stand til å veksle mellom ulike roller - også i forhold til den enkelte pasient: medspiller, støttespiller, psykoterapeut, somatisk lege og om nødvendig, vokter eller kontrollør.

\section{Kjerneholdningene}

Det grunnleggende menneskesynet er troen på at alle mennesker kan få det noe bedre, at mennesker som har rotet seg opp i uheldige livssituasjoner, likevel kan ha prøvd å gjøre det beste ut av sin situasjon. De må derfor møtes med dyp respekt. Psykiateren bør i stor grad tåle usikkerhet og forvirring og at det ikke alltid er noen klar fasit eller veldefinerte diagnostiske prosedyrer eller 
behandlingstiltak å gripe til. Hver pasients lidelse og historie er «unik», og psykiateren bør alltid være interessert i pasientens perspektiv på sine problemer, på årsaksforhold og hjelpetiltak.

Psykiateren bør forstå at pasienters bedring og utvikling ofte må ta tid og forutsetter selvmedvirkning. Han eller hun må ha stor respekt og toleranse for de irrasjonelle og ubevisste krefter hos pasienten og seg selv og jobber derfor hele livet med seg selv som et viktig instrument. Psykiateren må tåle å bli urettmessig gjort til «den onde». De må være åpne for kritikk og ikke gå til motangrep på pasienter eller pårørende (6). Psykiateren bør ta hensyn til at relasjonen til pasienten og familien kan være uhyre viktig for behandlingsresultatet og sykdomsforløpet.

\section{Er det mulig å opprettholde en slik psykiateridentitet?}

Effektivitetskravet og forventninger om at alt skal kunne ordnes raskt og effektivt, preger helsevesenet, som resten av samfunnet. Psykiaterens rolle kan bli mer og mer å stille diagnoser, administrere medisinering og mindre og mindre å være behandler selv. Man blir administrator av andres hjelpetiltak. Dermed blir psykiateren uten personlig kjennskap til og empati med dem som skal hjelpes. Hvis psykiateren ikke får utøve en innsats hvor kunnskap om både biologi/medisin, psykologi og sosiale forhold integreres hos den samme terapeut, kan psykiateren snart erstattes av psykologer (i psykoterapi), allmennmedisinere (for medisiner/psykofarmaka) og sosionomer (for tiltak rettet mot miljøfaktorer).

Faget psykiatri må aktivt arbeide for å integrere all ny kunnskap fra biologisk, psykologisk og miljørettet forskning til en helhetlig biopsyksosial modell for forståelse av psykiske lidelser. Under et effektivitetspress, kan det være fristende å bruke bare deler av modellen og lukke øynene for pasientproblemer som krever at hele modellen tas i bruk. Da kan psykiateridentiteten bli splittet i en psykoterapiidentitet, en biologiidentitet og en sosialpsykiatrisk identitet. Uten psykiaternes integrerende funksjon kan vi få en ytterligere fragmentering av behandlingen av mennesker med psykiske lidelser (7).

Hva er forutsetningene for å oppretthode en slik psykiateridentitet som her er omtalt? Det er særlig fire forutsetninger som peker seg ut:

- Psykiatrien må aktivt arbeide for å opprettholde en helhetlig biopsykososial modell for forståelsen av psykiske lidelser og motsette seg å basere virksomheten på utvalgte deler av modellen (f.eks. biologi, psykologi eller miljø).

- Det må være tid og rom nok for psykiateren til å bygge opp tillit (8) hos den enkelte pasient og familie (8). Uten tillit blir diagnosen lett feilaktig og etterlevelsen av behandlingen dårlig.
- Psykiateren må ha kompetanse og handlingsrom nok til selv å kunne bruke hele spekteret av effektive behandlingsmetoder, ikke bare være medisinutdeler og bakspiller for andre faggrupper.

- Psykiaterens oppgave må i hovedsak være hjelper og samarbeidspartner for pasient og pårørende, og ikke i hovedsak dørvakt, utkaster og vokter.

Både politikere, psykiatere, pasienter og pårørende har i dagens heletjeneste en stor og felles utfordring.

Oppgitte interessekonflikter: Ingen

Litteratur

1. Erikson E. Identity: Youth and crisis. New York, NY: Norton, 1968

2. Haugen O. Gule vengeslag i februar. Bergen: Såmbåndet forlag, 2005.

3. Molander A, Terum LI, red. Profesjonsstudier. Oslo: Universitetsforlaget, 2008.

4. Zubin J. Vulnerability: a new view of schizophrenia. Clin Psychol 1975; 29: 16-8.

5. Vaglum P. Irrasjonelle faktorer i lege-pasient-forholdet. Tidsskr Nor Lægeforen 2002; 122: 1906 -9.

6. Vaglum S. Kritikken mot psykiatrien: Hva kan psykiatrien gjøre noe med? Tidsskr Nor Lægeforen 1990; 110: 1728-30

7. Vaglum P. Revisjonen - en annerledes lærebok psykiatri. Oslo: Universitetsforlaget, 2004.

8. Skirbekk H. The patient's trust. Theoretical analyses of trust and a qualitative study in general practice consultations. Doktoravhandling. Oslo: Universitetet i Oslo, 2008

Manuskriptet ble mottatt 9.3. 2009 og godkjent 16.4. 2009. Medisinsk redaktør Anne Kveim Lie. 